ELORE (ISSN 1456-3010), vol. 20 - 1/2013.

Julkaisija: Suomen Kansantietouden Tutkijain Seura ry.

[http://www.elore.fi/arkisto/1_13/ahola.pdf]

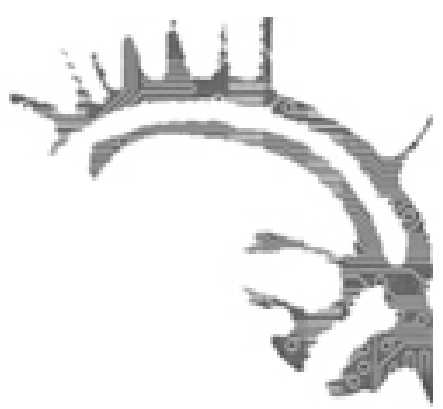

\title{
KIRJA-ARVIO
}

\section{VAIKEASTI MÄÄRITTYVÄT KOHTALOTTARET}

BEK-PEDERSEN, KAREN 2011: The Norns in Old Norse Mythology. Edinburgh: Dunedin. 224 sivua.

\section{Joonas Ahola}

Kolme ihmisten kohtaloita punovaa nornaa (muin.isl. norn) eli kohtalotarta kuuluu muinaisskandinaavisen mytologian vakiintuneimpiin kuviin. Siihen viitataan tyypillisesti puhuttaessa muinaisskandinaavisesta kohtalouskosta sekä mytologian abstrakteista ulottuvuuksista ja eskatologiasta. Huolimatta kuvan keskeisyydestä ja toistumisesta erilaisissa myyttistä maailmankuvaa käsittelevissä kuvauksissa ja tutkimuksissa sen taustaa ja merkitystä on tutkittu suhteellisen vähän. Folkloristisesti orientoitunut skandinavistikko, tutkija Karen Bek-Pedersen on selvittänyt näiden kolmen kohtalottaren olemusta laajan muinaisskandinaaviseen uskomusmaailmaan liittyvän aineiston avulla, jota hän tulkitsee lähinnä lähdekriittisin metodein. Käsiteltävänä olevan tutkimuksen tavoite on purkaa stereotyyppisen kuvan perusteet ja tuoda ne kriittisen tarkastelun kohteeksi sekä hakea nornien tekstuaalisten esiintymisten takaa viikinkiaikaan palautuvaa kohtalouskon järjestelmää, joka kokoaisi yhteen ja selittäisi esiintymisten näennäisen monimuotoisuuden. Samalla Bek-Pedersen esittelee mytologisen maailman naishahmot laajemminkin ja pohtii, löytyykö naishahmojen ryhmittelyyn ylipäätään tyhjentäviä perusteita. Johtopäätöksissään Bek-Pedersen ei pääse yksioikoisiin vastauksiin, mutta hän kirjoittaa itsekin, että teoksen tarkoitus on pikemmin avata keskustelua kuin päättää se. 
Joonas Ahola: Vaikeasti määrittyvät kohtalottaret

\section{MUINAISET USKOMUKSET JA KIRJALLISTEN LÄHTEIDEN ONGELMAT}

Tutkimuksen pääasiallisena lähteenä on Islannissa 1200- ja 1300-luvuilla kirjoitettuja mytologisia ja mytologiaan viittaavia runo- ja proosatekstejä. Edda-runot sekä mytologisia kertomuksia proosamuodossa käsittävä niin kutsuttu Snorra Edda ovat tutkimuksen tärkeimpiä lähteitä, mikä on ymmärrettävää, sillä ne tarjoavat täsmällisintä ja suorinta tietoa mytologisista hahmoista. Nämä tekstit on tuotettu ympäristössä, joka oli ollut käännytetty kristinuskoon jo parisataa vuotta aiemmin. Tekstit perustuvat suulliseen traditioon, jonka Bek-Pedersen useimpien muiden tutkijoiden tapaan katsoo kantavan muistoa pakana-ajan uskomusjärjestelmistä. Bek-Pedersen huomauttaa, että jo itse skandinaavinen mytologia oli yhtenäistä myytti-, uskomus- tai maailmankatsomusjärjestelmää luultavammin hajanainen joukko erilaisia myyttejä, uskomuksia ja maailmankatsomuksia. Hänen mukaansa tämä varioiva traditio, jonka ilmaisuja erilaisissa mytologiaan viittaavissa teksteissä tavataan, heijasteli kuitenkin yhtenäistä tematiikkaa. Tätä tematiikkaa tutkimus hakee.

Bek-Pedersen käyttää monipuolisesti myös muuta aineistoa tukena päätelmilleen. Tämä aineisto yltää islantilaisesta saagakirjallisuudesta ja siihen kuuluvasta skaldirunoudesta myös lähikulttuurien tekstuaalisiin tallenteisiin, ja paikoin Bek-Pedersen nostaa esiin myös muun muassa arkeologisia löytöjä pohdintojensa tueksi. Tutkimuksessa arvioidaan näitä lähteitä lähinnä sen mukaan, missä määrin niiden voi katsoa tarjoavan tietoa esikristillisestä mytologisesta järjestelmästä. Sen perusteella esimerkiksi Snorri Sturluson, Snorra Eddan kirjoittajaksi oletettu islantilainen, joka eli 1200-luvun ensimmäisellä puoliskolla, luetaan käsityksineen kansanomaisesta mytologiasta "ulkopuoliseksi", koska hän eli jo pari sataa vuotta kristillistettynä olleessa maassa ja oli kirkollisen koulutuksen saanut mies. Voi olla kuitenkin paikallaan kysyä, eikö 1200-luvun valistunut kirjoittaja voinut olla luotettava ja kenties jopa joissakin suhteissa luotettavampikin tulkintapohja kuin esimerkiksi irralliset mytologisten runojen tekstikatkelmat ilman vihiäkään niiden käyttökontekstista.

Tutkimuksen lähteistö on hajanainen eikä paljoakaan pysty kertomaan suoraan juuri viikinkiajan skandinaavisesta uskomusjärjestelmästä, mutta Bek-Pedersen pitää urheasti kiinni lähtötilanteensa tutkimuskysymyksistä ja pohtii ansiokkaasti aineistonsa heikkouksia suhteessa valittuun niihin. Yksittäisistä tekstikatkelmista hahmotettava variaation perustana oleva tematiikka jää väistämättä jokseenkin hataralle pohjalle. Se osoittaa tutkimuksen lähtötilanteen - vakiintuneen käsityksen dekonstruktion - relevantiksi. Olisi pikemminkin outoa, mikäli kulttuurisesti keskeiseksi osoitettavan abstraktin käsityksen kansankulttuurisille ilmauksille olisi tarjota yksioikoinen selitysmalli, etenkin kun ilmaukset on tuotettu pitkällä aikajänteellä. Tutkimus on juuri tulostensa moninaisuudessa merkittävä analyyttinen kontribuutio aiheeseen.

\section{KOHTALOKKAITA NAISHAHMOJA}

Mytologiassa ja mytologiaan viittaavissa teksteissä esiintyy useita soturien kohtaloon liittyviä naishahmoja, joiden olemuksesta ja keskinäisistä suhteista on tutkimushistoriassa 
ollut useita käsityksiä. Keskeisimmät hahmot Bek-Pedersen jaottelee norniin (nornir), valkyyrioihin (valkyrjur) ja jumalattariin (disir)

Dis (mon. disir) käsitetään tutkimuskirjallisuudessa usein kattavasti naispuoliseksi jumalhahmoksi ja kaikki mytologiset naishahmot alikategorioiksi. Bek-Pedersenin mukaan tämä on kuitenkin yksinkertaistamista, ja vaikka monet lähdetekstit tukevat tätä käsitystä, on dísir hyödyllisempää erotella muista. Näiden kohdalla näyttää olleen rituaalista toimintaa, joka liittyi hedelmällisyyteen ja kuolemaan. Ne esiintyvät teksteissä kuitenkin aina anonyyminä entiteettinä. Valkyyriat, joiden eri tekstiyhteyksissä kerrotaan noutaneen taistelukentillä kuolleet soturit sodanjumala Óðinnin saliin, liitettiin toki kuolemaan mutta sotimisen kautta ilman yhteyksiä hedelmällisyyteen. Myyttisissä teksteissä esiintyy toimijoina paljon erikseen nimettyjä valkyyrioita, kun taas kollektiivina ne esiintyvät lähinnä viittauksissa.

Nornat näyttävät edustavan jääväämättömyyttä laveassa ja saavuttamattomassa merkityksessä. Norniin viitataan, mutta ne esiintyvät toimijoina ani harvassa tekstissä. Nornat liitetään teksteissä lähinnä kuolemaan ja tuomioon, mutta myös muihin elämän siirtymäkohtiin. Nornat esiintyvät lähinnä anonyyminä kollektiivina. Bek-Pedersenin mukaan nornat esiintyvät lähteissä suurten muutosten taustalla häilyvinä hahmoina, kun taas disir olivat enemmän läsnä arjessa (s. 66).

Näiden hahmojen funktiot, jotka ovat hahmoteltavissa kertomuspohjalta, ovat osittain päällekkäisiä, minkä Bek-Pedersen osoittaa kuvaavasti. Keskittyessään norniin hän esittelee laajasti eri lähteistä löytyvät viittaukset ja pohtii niiden merkityksiä viittausten tekstiympäristön ja ilmaisun herättämien assosiaatioiden pohjalta. Esimerkiksi kehrääminen ja kutominen on liitetty kohtalottariin. Tälle työlle oli viikinkiaikaisessa Islannissa erotettu oma tilansa maakellareissa (isl. dyngja), irrallaan miehisestä toimintapiiristä. Bek-Pedersen assosioi makkellarin kohtuun ja kutomisen ihmisenalun kehittymiseen. Kohtalottarillahan oli sormensa pelissä ihmisen syntymässä heidän määrittäessään ihmisenalun kohtalon (s. 110-113).

\section{KEHRÄ̈̈MINEN, PUNOMINEN, KUTOMINEN JA PUHE}

Bek-Pedersen huomauttaa, ettei yhdessäkään lähteessä puhuta kehräävistä kohtalottarista. Sen sijaan esimerkiksi Eddan sankarirunoihin kuuluvassa Helgakviða Hundingsbana I:ssä esiintyy nornia, jotka mitä ilmeisimmin punovat tekstiiliä. Lisäksi Poltetun Njállin saagan (Brennu-Njáls saga) loppupuolella on pitkä runo, jota kutsutaan "Darraðarljóðiksi" (keihäsruno). Runossa valkyyriat kutovat odottavan taistelun alla kangasta. Bek-Pedersen näkee kankaankutomiskuvauksessa paljon symbolisia kuvia, jotka perustelisivat runon kertovan kohtaloiden kutomisesta. Kutovat naishahmot eivät ole nornia vaan valkyyrioita, mutta runon mukaan heillä on valta päättää taistelun kulusta. Runon sepittäjälle (saaga kirjoitettiin 1200-luvun lopulla, mutta runo saattoi olla sepitetty huomattavasti aiemmin) valkyyriat kävivät hyvin myyttisiksi hahmoiksi, joilla oli valta päättää miesten kuolemasta taistelussa.

Tässä esimerkissä, kuten muuanna kirjassa useissa kohdin, Bek-Pedersen seuraa yksittäisiä runokuvia ja kertomusaihelmia myös toisiin traditioihin. Läheskään aina tämä 
ei johda selvennyksiin, mutta tutkimusprosessin ja pohdintojen esittely on innostavaa ja avaa ovia mahdollisille uusille tulkinnoille tulevaisuudessa. Joissakin sukusaagoissa kehrääminen on liitetty taikuuteen, mutta Bek-Pedersen toteaa aivan oikein, että silmänkääntötemput, joista näissä kohdissa on kyse, eivät liity kohtalottariin. Bek-Pedersen nostaa esiin myös tekstiilin ja tekstin semanttiset yhteydet: puhe ja kutominen (ja miksei kertomus ja punominen) liittyvät yhteen paitsi symbolisella, myös etymologisella tasolla. Tämän yhteyden nojalla kutominen on Bek-Pedersenin mukaan tulkittavissa siis jumalallisen performatiivin, todeksi käyvän puheen, symboliseksi ilmaisuksi, joka on sijoitettu naisten elämänpiirin salaperäiseen kolkkaan, kudontakellariin. Pohdinta on kiehtovaa, mutta ilman konkreettista evidenssiä kansanomaisen kulttuurin piiristä, jää hiukan kellumaan.

Tämä näkemys saa toisaalta tukea yhteydestä, jonka Bek-Pedersen esittää kohtalon (muin.isl. ørlog) ja lain (muin.isl. $l$ gg) välille, jonka perusteella kohtalottaret olisivat jonkinlaisia metafyysisiä lainlaatijoita ja tuomareita. Hän esittää aivan oikein, että laki merkitsi keskiaikaisessa Skandinaviassa enemmän kuin pelkkää sääntöjen kokoelmaa: se määritti kulttuuria ja identiteettiä yleisemmin ja määritti siis yksilöä yhtä lailla vääjäämättä kuin kohtalo. Laki oli kuitenkin luonteeltaan toimintaa ohjaileva, kun taas kohtalo absoluuttinen.

Kohtalon mieltäminen lakina ja nornat tämän lain säätäjinä ja valvojina on kiinnostava pohdelma, mutta säilyneet tekstit tukevat näkemystä vain välillisesti. Sen sijaan kohtalon, ennustamisen ja puheen välinen yhteys on esitetty kiinnostavasti, ja se on relevantti nornien yhteydessä (joskaan nornia ei esitetä juuri koskaan puhumassa, vaan yhteys todentuu lähinnä edellisessä luvussa esitetyn kutomisen ja puhumisen välisen yhtymäkohdan kautta). Bek-Pedersen pohtii asianmukaisesti teksteissä ilmaistuja kohtalokäsityksiä monessa kohtaa ja eri näkökulmista. Filosofiselle tasolle Bek-Pedersen yltää esimerkiksi pohtiessaan kohtalon ja ajan suhdetta (s. 88-91). Bek-Pedersen määrittää kohtalon subjektin ominaisuudeksi, ei ulkoisten tapahtumien suhteita kuvaavana mitattavana suureena kuten aika tai kausaliteetti. Tämä näkökulma kuvaa hyvin tutkimuksessa keskeiseksi noussutta kohtalon mieltämistä ihmisen suorastaan rakenteellisena, elimellisenä ominaisuutena, jonka nornat kutovat, punovat tai lausuvat osaksi ihmistä maakellarikohdussa. Tällainen käsitys kohtalosta huokuu myös esimerkiksi saagakirjallisuudesta, ilman mainintoja nornista, eikä Bek-Pedersenin tulkinta nornien olemuksesta ole sen kanssa ristiriidassa.

\section{(KOHTALOKKAAT?) LOPPUSANAT}

Aiheen käsittely etenee tunnollisesti aineiston ehdoilla, mikä kuuluukin hyvään perustutkimukseen, mutta aika ajoin teoksen yhtenäisyys kärsii siitä. Pidän silti aineiston huolellista esittelyä ja käsittelyä tutkimuksen ehdottomana vahvuutena. Se tuo tehokkaasti esiin kohtalon henkilöitymän (runokuvan) monikäyttöisyyden erilaisissa ilmaisutavoissa ja -tilanteissa. Teos on pyrkimys naispuolisten kohtalottarien ja näiden läheisten hahmokategorioiden erittelemiseen ja määrittelemiseen, mutta tutkimus 
päätyy tuloksiin, jotka kuvaavat pikemmin mytologisten runokuvien luovaa käyttöä erilaisissa tekstiympäristöissä. Bek-Pedersen seuraa huolellisesti monia kohtalottariin liitettyjen aspektien merkityksiä, viittauksia ja assosiaatioita, jotka yhtäältä syventävät kuvaa ja toisaalta osoittavat, kuinka vaikeaa voi olla määrittää abstraktio hajanaisten lähteiden pohjalta. Tutkimuksen tavoitteena on tunnistaa nornien paikka ja funktio viikinkiaikaisessa skandinaavisessa mytologiassa. Lähteet ovat kuitenkin huomattavasti myöhempiä huolimatta siitä, että osa lähteistä, esimerkiksi monet skaldirunot, sepitettiin jo viikinkiajalla. Eri-ikäiset ja eri alueilta olevat, hajanaiset ja erityyppiset aineistot johtavat väistämättä vaillinaisesti eheään teoriaan. Bek-Pedersen kertoi minulle itse, että hän jätti kohtalokäsitysten myöhemmän (kristillisen) kerrostuman teksteissä vähälle huomiolle, koska se olisi edellyttänyt koko keskiaikaisen kristillisen ajattelun avaamista ja suhteuttamista tekstien ilmaisemaan kansanomaiseen ajatteluun.

Johtopäätöksiin ja tuloksiin Bek-Pedersen pääsee monesti monimutkaisten viitteellisten yhteyksien kautta (kutominen - puhe - kohtalokas puheakti - laki) joissa on kussakin vajavuutensa, eivätkä itse tutkimuskysymyksiin liittyvät johtopäätökset olekaan tutkimuksen vahvinta antia. Vähäiset johtopäätösten mahdollisuudet eivät ole lopulta edes tutkimuksen heikkous, vaan kenties juuri vahvuus: tutkimuksen lähtökohtana on ollut kuva, joka on osoittautunut (osin) vääräksi. Kuvan herättämiä assosiaatioita seuratessaan Bek-Pedersen yltää kiinnostaviin tulkintoihin, mutta joutuu vetäytymään johtopäätöksissään kerta toisensa jälkeen, mikä on entistä vahvempi peruste vakiintuneen vanhan kuvan rikkomiselle.

On helppo ennustaa, että teos palvelee muinaisskandinaavisen kohtalokäsityksen ja kohtalottarien tutkimuksen perusteoksena vielä pitkään.

Filosofian lisensiaatti Joonas Ahola on folkloristiikan jatko-opiskelija Helsingin yliopistossa. 